\title{
Relationship between Monthly Rainfall in NW Peru and Tropical Sea Surface Temperature
}

\author{
Juan Bazo, ${ }^{1,2}$ María de las Nieves Lorenzo, ${ }^{1}$ and Rosmeri Porfirio da Rocha ${ }^{3}$ \\ ${ }^{1}$ Faculty of Sciences, Campus de Ourense, University of Vigo, 32004 Ourense, Spain \\ ${ }^{2}$ Peruvian National Meteorological and Hydrological Service (SENAMHI), Casilla 11 1308, Lima 11, Peru \\ ${ }^{3}$ Department of Atmospheric Sciences, Institute of Astronomy, Geophysics and Atmospheric Sciences, University of São Paulo, \\ São Paulo, SP, Brazil \\ Correspondence should be addressed to Juan Bazo; jbazo@senamhi.gob.pe
}

Received 23 October 2012; Revised 22 January 2013; Accepted 26 February 2013

Academic Editor: Klaus Dethloff

Copyright (c) 2013 Juan Bazo et al. This is an open access article distributed under the Creative Commons Attribution License, which permits unrestricted use, distribution, and reproduction in any medium, provided the original work is properly cited.

This study assesses the relationship between global sea surface temperature (SST) and a regional index of rainfall (NWPR) in PiuraTumbes, a coastal region in northwestern Peru, over the period 1965-2008 by means of the Pearson product-moment correlation. The results show that this area is strongly influenced by three indices: El Niño-Southern Oscillation (ENSO) Niño3.4 region, the Indian Ocean Dipole (IOD), and the equatorial Atlantic Oscillation (ATL3). In particular, a positive correlation has been found with the two first indices (Niño3.4 and IOD) and a negative one with ATL3 with several months of delay. This allows developing a forecast regression model for monthly rainfall in NW Peru with months in advance. The results show that linear regression model is not enough to provide satisfactory results; however, a nonlinear regression model improves considerably the prediction of rainfall anomalies in NW Peru.

\section{Introduction}

Sea surface temperature (SST) is a reliable variable to be used as a forecast tool. The high inertia of the sea makes the analysis of SST anomalies useful in monthly and seasonal rainfall prediction in some areas of the globe [1].

Previous works have shown the influence of anomalies in sea level pressure and precipitation variability on changes in the SST [2], in the Pacific area. Other works have analyzed the influence of global scale SST patterns on temperature and rainfall [3-6]. In particular, North Atlantic SST is related to precipitation anomaly in different European areas: Italy, Iceland, England, Iberian Peninsula, and Africa [7-10]. Also, prior researches have indicated some relationship between different areas of SST and precipitation in Peru and South America: Lagos et al. [11] employed lag-correlation analysis for statistical precipitation forecast from SST anomalies in the commonly used El Niño regions and precipitation in Peru; Woodman [12] found high correlation between rainfall in Piura and SSTs in various sectors of the eastern Pacific, allowing the development of a nonlinear regression model to forecast (seasonal or monthly) precipitation in that region; Vuille et al. [13] observed that SST anomalies in the tropical Atlantic are closely related to the rainfall in the eastern Andes; González and Vera [14] found significant lagged correlations between SST anomalies over the tropical Indian Ocean and rainfall variability in Southern Andes.

Some researches explained that rainfall variability in South America is dominated by patterns such as El NiñoSouthern Oscillation (ENSO), Intertropical Convergence Zone (ITCZ), Atlantic SST $[15,16]$, Indian Ocean Dipole (IOD) [17-19], and Madden-Julian Oscilation [20], with distinctive time scales, that is, intraseasonal, interannual, decadal, and long-term variations. Each pattern is closely related to SST variations of the corresponding time scales, implying the significance of the atmospheric ocean coupling to the variability of the hydrological cycle.

The climate on the northern coast of Peru is very special for two reasons: its high rainfall variability in time and its high correlation with the ENSO phenomenon. On the other hand, Tumbes and Piura regions are of great importance for the Peruvian economy due to the large fishing industry and 


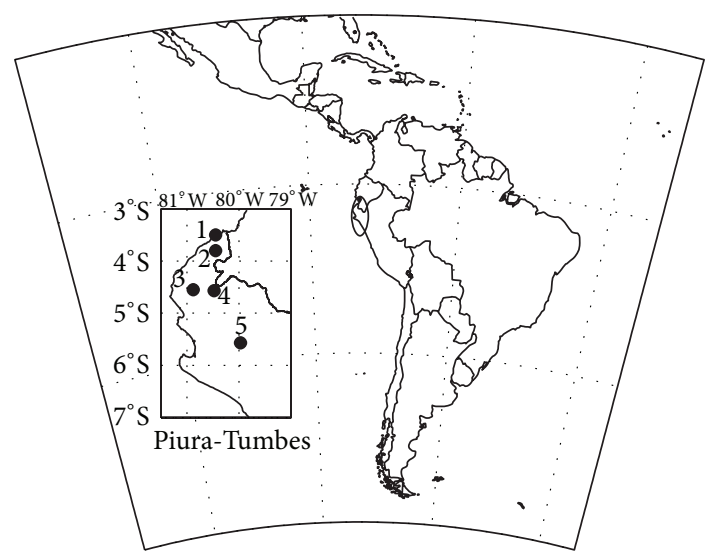

FIGURE 1: Location of Tumbes-Piura region and of the meteorological stations (numbers from 1 to 5 ).

agriculture. In addition, Tumbes and Piura are important tourist centers, generating important profits to the country. However, this region is set out to significant climatic variability, mainly due to the ENSO phenomenon with recurrent droughts and direct impacts on the biotic and physical coastal environments, both marine and terrestrial [12, 21-24]. This makes the region an area particularly sensitive to climate change impacts.

In this study, we investigate the association between global SST anomalies for 1965-2008 and monthly rainfall over Tumbes and Piura regions, in the northwestern of Peru. The main objective of this work is to investigate the potential for statistical precipitation forecasts based on global SST anomalies. Additionally, forecast regression models are proposed.

The paper is organized as follows. Details regarding the study area are provided in Section 2. Data and methodology used are described in Section 3. Results are presented and discussed in Section 4. Finally, conclusions are drawn in Section 5 .

\section{Study Area}

Tumbes-Piura is a coastal region in northwestern Peru (from $3.50^{\circ} \mathrm{S}$ to $6.37^{\circ} \mathrm{S}$ and from $79.21^{\circ} \mathrm{W}$ to $81.33^{\circ} \mathrm{W}$ ) (Figure 1 ). This region is located within a sharp climatic boundary between a warm and humid tropical area to the north (western Ecuador), and a cool desert land which borders the South Pacific Ocean southwards along some $3,000 \mathrm{~km}\left(5^{\circ}-32^{\circ} \mathrm{S}\right)$. The north Peruvian coast lies also a major oceanographic limit which shows a strong thermal gradient between warm equatorial and the cold southwestern seawaters of South Pacific coast. This water is cooled down by cold currents and active upwelling processes: it is the area where the Peruvian (Humboldt) current and the Equatorial counter current are both deflected westwards, towards the central Pacific Ocean $[25,26]$.

A semitropical and tropical savanna in the center and the north coast and semiarid in the southern coast climates characterize the Tumbes-Piura region. Piura has tropical-dry climate monsoon weather; the average temperature is $27^{\circ} \mathrm{C}$

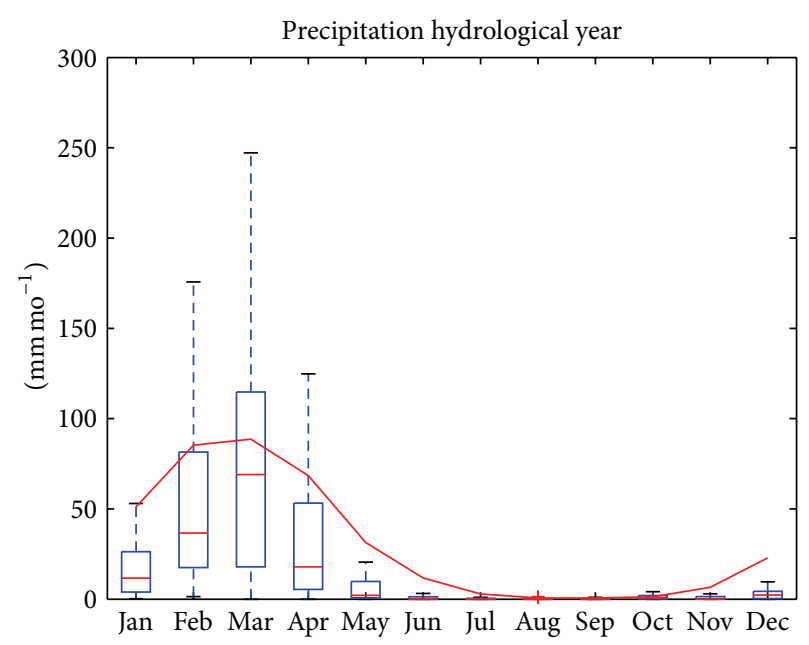

FIGURE 2: Annual hydrologic cycle corresponding to the monthly mean precipitation (red solid line) in the period 1965-2008. See text for further details.

throughout the whole year. Rainfall is scarce from May to November, and rainy season occurs from December to April at discontinuous rates. Rainfall varies in normal years from 100 to $300 \mathrm{~mm}$, and it has a much defined dry season due to normal influence of ENSO. During the El Niño phenomenon, the rainfall is copious and makes the dry ravine becomes alive; the amount of precipitation in these areas exceeds more than $500 \%$ its normal value. In Figure 2, we have shown the mean annual hydrologic cycle and its variability in TumbesPiura region from 1965 to 2008. In this figure, the solid line represents the monthly mean values, solid line inside each box indicates the monthly median, the lower/upper whisker represents the minimum/maximum rainfall, and the lower/upper boxes represent the first/third quartiles, respectively. The period considered includes three strong El Niño events (1971-72, 1982-1983, and 1997-1998). Two clearly defined seasons (wet and dry) can be distinguished in Figure 2, with the wet season occurring from December to May and the dry one from June to November. In Figure 2, it is evident that the wet season is characterized by large rainfall interannual variability. Three synoptic situations can temporarily produce rainfall in the form of the light rain showers or isolated thundershowers. All the three are related to an El Niño event: large-scale changes in the atmospheric circulation and Pacific Ocean currents favor the development near the equatorial trough, cyclonic activity, and/or diurnal heating [27].

2.1. Teleconnection Influences on Rainfall in the Study Area. The impacts of ENSO over Peru are well documented [1116], Waylen and Poveda [28], 2002, Douglas et al. [29], Tapley and Waylen [30], Goldberg et al. [31], and Horel and CornejoGarrido [32], but the effects of the Indian Ocean and Atlantic Ocean variability onto Peru rainfall are less understood. Previous studies show that Indian Ocean can remotely affect the atmospheric circulation over South America [33] leading to a significant impact on precipitation [17]. Drumond and 
TABLE 1: Names and locations of the meteorological stations with rainfall data from 1965 to 2008 .

\begin{tabular}{lccc}
\hline Station & Altitude $(\mathrm{m})$ & Latitude $(\mathrm{S})$ & Longitude $(\mathrm{W})$ \\
\hline (1) Puerto Pizarro & 1 & $-3^{\circ} 30^{\prime}$ & $-80^{\circ} 27^{\prime}$ \\
(2) Rica Playa & 98 & $-3^{\circ} 48^{\prime}$ & $-80^{\circ} 27^{\prime}$ \\
(3) Pananga & 440 & $-4^{\circ} 33^{\prime}$ & $-80^{\circ} 53^{\prime}$ \\
(4) Lancones & 135 & $-4^{\circ} 34^{\prime}$ & $-80^{\circ} 29^{\prime}$ \\
(5) Virrey & 275 & $-5^{\circ} 34^{\prime}$ & $-79^{\circ} 58^{\prime}$ \\
\hline
\end{tabular}

Ambri [18] reported that warm SST anomalies in the Indian Ocean reach South America via teleconnection pattern, which potentially induces changes onto the circulation and rainfall over the continent during austral summer. They have showed composite of DJF precipitation anomalies for the warm IOD extreme events impacting southern Brazil and northwestern Peru. Likewise, Taschetto and Ambrizzi [19] explained a remote teleconnection pattern between the warming of tropical Indian Ocean and the atmospheric circulation/precipitation over South America. In this study, they presented results from observations, reanalysis, and simulations providing evidences of the modulation of South America summer rainfall by Indian Ocean SST variability via modifications of the Walker circulation pattern and wavetrain teleconnection. In these experiments, they have calculated a partial correlation excluding the influence of El Niño index, obtaining a positive signal in seasonal precipitation over northwestern Peru.

In the same way, Vuille et al. [34] and Yoon and Zeng [35] explained a different remote mechanism associated with Atlantic Ocean affecting rainfall over South America. Besides, teleconnections of the Atlantic, Indian, and Pacific Oceans were identified by Wang et al. [36] to affect the South America. Associated with the interbasins, SST variability showed two zonal anomalous Walker circulation cells, one over tropical Pacific Ocean and another one over tropical Atlantic Ocean [36].

\section{Data and Methods}

Monthly precipitation data from 1965 to 2008 were obtained from the database of Peruvian National Meteorological and Hydrological Service (SENAMHI). These data underwent a quality control procedure with substitutions made for poor quality and some missing data, similar to the one used in the NCDC (National Climate Data Center, NOAA) for GHCN (Global Historical Climate Network) database [37]. Quality control for these series gave a result of only $0.01 \%$ of missing data and $90 \%$ of correlation with neighbor stations.

Table 1 summarizes the geographic characteristics of the meteorological station used in this study, and their locations are given in Figure 1. Averaging rainfalls corresponding to the five stations can constitute a valid procedure in our study because they are highly correlated. The correlations for monthly rainfall among them vary from 0.84 to 0.93 with a statistical significance of $90 \%$.

The rainfall regime shows important interannual variations (Table 2), which can be characterized in terms of the
TABLE 2: Monthly mean ( $\mathrm{mm})$, standard deviation ( $\mathrm{mm}$ ), and the coefficient of variation $(\mathrm{CV})$ of the mean rainfall from the five stations (see Figure 1) in NW Peru.

\begin{tabular}{lccc}
\hline Month & Mean & Standard deviation & CV (\%) \\
\hline January & 52 & 36 & 70 \\
February & 88 & 41 & 47 \\
March & 117 & 42 & 36 \\
April & 60 & 35 & 59 \\
May & 27 & 57 & 209 \\
June & 7 & 14 & 190 \\
July & 1 & 10 & 828 \\
August & 0 & 1 & 325 \\
October & 1 & 1 & 63 \\
November & 2 & 10 & 440 \\
December & 16 & 30 & 187 \\
\hline
\end{tabular}

mean, standard deviation, and the coefficient of variation $(\mathrm{CV})$ :

$$
\mathrm{CV}=100 * \frac{\sigma R i}{R i}
$$

where $R$ is the rainfall, the subscript ( $i)$ refers to the month, and $(R i)$ and $(\sigma R i)$ are the mean and the standard deviation, respectively. The $\mathrm{CV}$ is a dimensionless number, which ranges from $36 \%$ in March to $828 \%$ in July, which is higher during the dry season.

Monthly rainfall was expressed as anomaly relative to the mean rainfall of the period 1965-2008. The nondimensional rainfall anomaly index NWPR (North Western Peru Rainfall index; Phillips and McGregor [8-10, 38]), adopted in the present study is defined as:

$$
\mathrm{NWPR}=100 \sum_{1}^{N}\left(\frac{X}{\bar{X}}\right),
$$

where $X$ is the monthly rainfall anomaly at one station in $\mathrm{mm}, \bar{X}$ is the station's mean annual rainfall in $\mathrm{mm}$, and $N$ is the number of stations. This index provides an adequate first approximation of monthly variations of the rainfall in the studied area.

SST was provided by NOAA/OAR/ESRL PSD (Smith and Reynolds [39]), and it is an extended reconstructed SST (ERSST; NOAA, ERSST-V3) obtained using the most recently available International Comprehensive Ocean-Atmosphere Data Set (ICOADS) SST and improved statistical methods that allow stable reconstruction using sparse data. This monthly analysis begins in January 1854, but due to the sparsity of data, the analyzed signal is heavily damped before 1880. Afterwards, the strength of the signal is more consistent over time. SST monthly averaged data are in a $2^{\circ} \times 2^{\circ}$ horizontal grid. In the present study, data were taken from January 1, 1965, through December 2008.

The values of the indices used, IOD (Indian Ocean Dipole), ATL3 (equatorial Atlantic Oscillation), and Niño3.4 (ENSO), were obtained from different sources. 


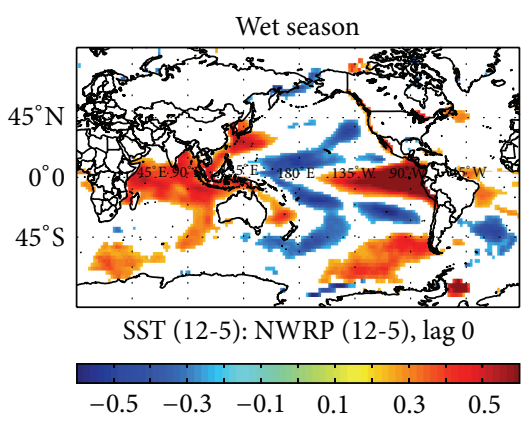

(a)

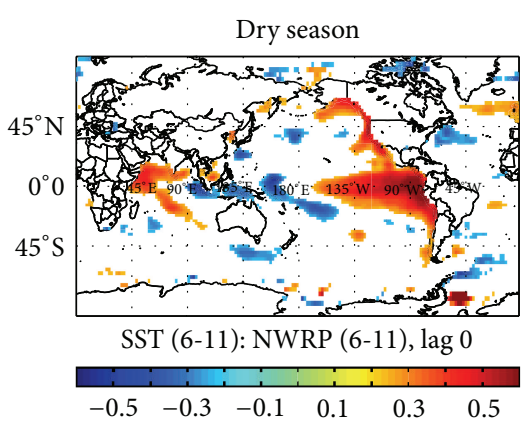

(d)

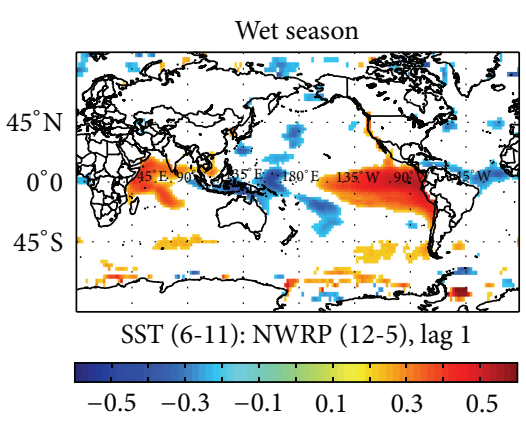

(b)

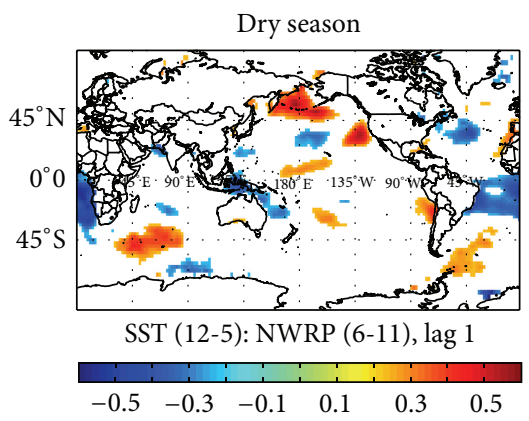

(e)

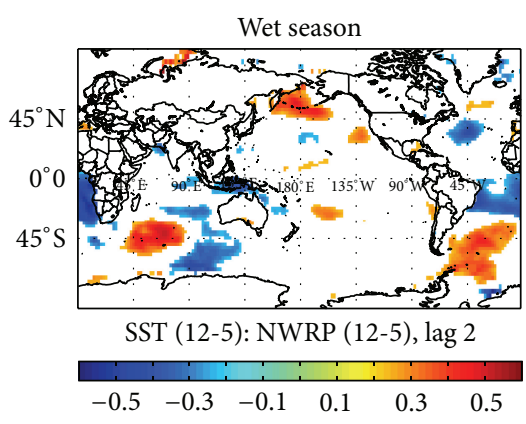

(c)

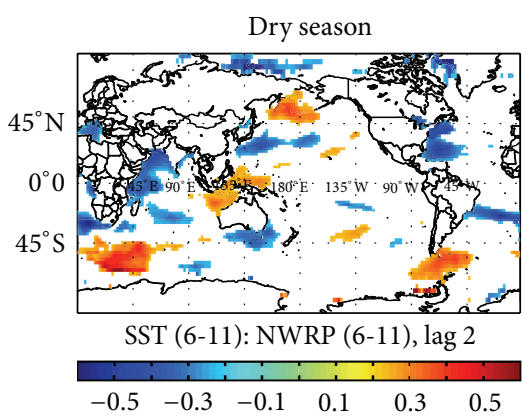

(f)

FIGURE 3: Correlation coefficient maps between SST and NWRP for wet ( $a, b$, and c) and dry (d, e, and f) and different season lags.

The intensity of the IOD is represented by anomalous SST gradient between western equatorial Indian Ocean $\left(50^{\circ} \mathrm{E}-\right.$ $70^{\circ} \mathrm{E}$ and $10^{\circ} \mathrm{S}-10^{\circ} \mathrm{N}$ ) and southeastern equatorial Indian Ocean $\left(90^{\circ} \mathrm{E}-110^{\circ} \mathrm{E}\right.$ and $\left.10^{\circ} \mathrm{S}-0^{\circ} \mathrm{N}\right)$. This gradient is named as Dipole Mode Index (DMI). When the DMI is positive (negative), then the phenomenon is refereed as positive (negative) IOD. The monthly values of this index were obtained from SST DMI dataset from 1958 to 2010 [33].

Following Zebiak [40], the ATL3 index was calculated as the SST anomaly in a region located in the central-eastern tropical Atlantic $\left(3^{\circ} \mathrm{S}-3^{\circ} \mathrm{N} ; 20^{\circ} \mathrm{W}-0^{\circ} \mathrm{E}\right)$.

The Niño3.4 SST anomaly index is an indicator of central tropical Pacific El Niño conditions (Trenberth [41]). It is an SST anomaly in the box $170^{\circ} \mathrm{W}-120^{\circ} \mathrm{W}, 5^{\circ} \mathrm{S}-5^{\circ} \mathrm{N}$ which was directly obtained from National Centers for Environmental Prediction (NCEP).

The Pearson product-moment correlation coefficient $(r)$ was considered in a first step to quantify the linear association between the SST of each $2^{\circ} \times 2^{\circ}$ grid square and NWPR index. The coefficient significance was assessed to be greater than $95 \%$ by means of Student's $t$-test. As it is possible to obtain a statistically significant correlation by simply correlating two random series, we applied a test for field significance considering the properties of finiteness and interdependence of the spatial grid. More details of the applied test are shown in $[8-10]$.

In a second step, the monthly correlations between the indices (Niño3.4, IOD, and ATL3) and NWPR were calculated considering 0-12 months of lags.

\section{Results}

4.1. Relationship between SST and Rainfall. The concurrent and lagged correlation between SST and NWPR were calculated considering a seasonal division and $0-2$ season lags. Two seasons were considered: one dry season from JuneNovember and other wet season from December-May as shown in Figure 2.

Figure 3 shows the correlation maps between SST and NWPR for wet and dry seasons with their respective season lags. Although the correlations have a significance of only $90 \%$ in the applied field tests, it is possible to observe three major areas of influence of SST on northwestern Peru's rainfall. These areas are the ENSO region in the equatorial Pacific for lag $0-1$ in the wet season and for lag 0 in the dry season; the Indian Ocean for lag 0-1 in the wet season and for lag 2 during dry season; the equatorial Atlantic Ocean for lag $1-2$ in the wet season and for lag 1 in the dry season.

If we analyze the areas of Figure 3, we find that all these are related with climate indices. In particular, we find that the area observed in the tropical Pacific Ocean could correspond with that used to calculate the Niño3.4. The area found in the Indian Ocean could be related with the region considered to calculate the IOD, while that area detected in the Atlantic Ocean is similar to the area used to define the ATL3 index (see Figure 4).

ENSO also affects other ocean basins through perturbations in the Walker circulation which induce changes in cloud cover, evaporation, surface winds, and hence the net heat flux entering these remote oceans. This "atmospheric bridge" 


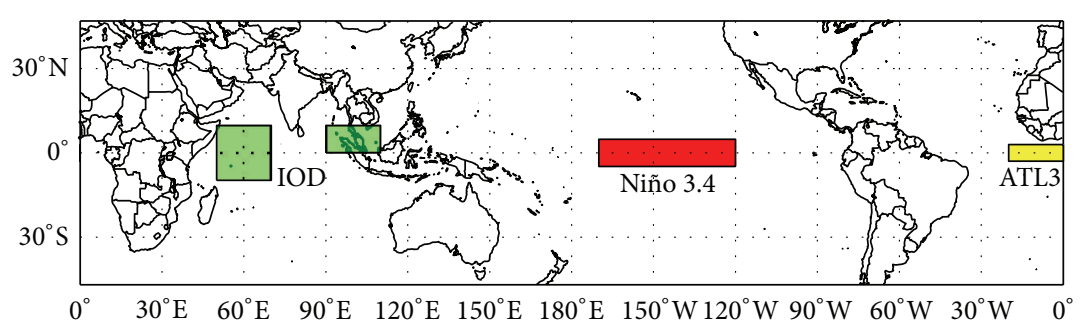

FIGURE 4: Location of SST areas used to calculate the indices IOD, ATL3, and Niño3.4.

leads to increased heat flux and positive SSTA in remote ocean basins such as the south China Sea, the Indian Ocean, and the tropical Atlantic, approximately 3-6 months after SSTA peak in the tropical Pacific, Klein et al. [42]. The remote warming of tropical oceans leads to a coherent zonal mean warming throughout the troposphere from $30^{\circ} \mathrm{N}$ to $30^{\circ} \mathrm{S}$ during El Niño events. The peak warming however lags behind tropical Pacific SST by approximately 4 months due to the lagged response of the remote oceans [43].

The present results led us to analyze the relationship between these three indices and precipitation in the NW Peru at monthly time scale and time lags from 0 to 12 months.

Figure 5 shows the correlations between different monthly indices and monthly NWPR index ( $x$-axis) and several lags ( $y$-axis). The correlation coefficients showed in Figure 5 can help to elaborate a prediction model at monthly time scale.

4.2. Regression Forecast Models. In view of the findings in Figure 5, a linear regression model to predict the anomalies of rainfall was constructed. To develop the model, we must analyze Figure 5 and select the indices and months suitable to predict rainfall in each month. For example, Figure 5 indicates that the indices ATL3 of April/May, IOD of October/November, and Niño3.4 of November show strong correlations with the rainfall of December. A possible linear regression model to predict the December rainfall would be:

$$
\begin{aligned}
Y^{m^{y}}= & \frac{a * \mathrm{SST}_{[-3,3][3,20 \mathrm{~W}]}^{m^{1}}}{\mathrm{ATL} 3} \\
& +\frac{b * \mathrm{SST}_{[-10,10][50 \mathrm{E}, 70 \mathrm{E}]}^{m^{2}}+c * \mathrm{SST}_{[0,10][90 \mathrm{E}, 110 \mathrm{E}]}^{m^{2}}}{\mathrm{IOD}} \\
& +\frac{d * \mathrm{SST}_{[-5,5][120 \mathrm{~W}, 170 \mathrm{~W}]}^{m^{3}}+e}{\mathrm{Niño3.4}}
\end{aligned}
$$

where $m^{y}=$ December, $m^{1}=$ April, $m^{2}=$ October, and $m^{3}=$ November.

During the period 1965-2008, this linear regression model to December rainfall provides a correlation of $\sim 0.45$ between the observed and predicted rainfall with a statistical significance of $95 \%$. The same is obtained to January rainfall with a similar model. The linear model can predict the extremes episodes, but it is not a suitable predictor in the normal years. The low values of correlation suggest that a linear regression model may not be the best solution to explain the relationship between SST indices and rainfall anomalies in NW of Peru.

In a previous work [12] assumed an exponential relationship between Piura precipitation and coastal SST. He proposed that if it were possible to predict the SST at the coast of NW Peru then would be possible to develop a rainfall prediction model. Following [12], in this present study, we assumed an exponential relationship between the NWPR rainfall and the SST of the ATL3, IOD, and Niño3.4 indices. The advantage of our study is that the influence of the indices presents several months of delay, and, in this way, knowing the temperature of these regions in particular previous months, we can elaborate a prediction of the rainfall in the next months. Therefore, considering the trend from April to November, we could make a prediction for December rainfall in NW Peru. We propose the following nonlinear model:

$$
\begin{aligned}
Y^{m^{y}}=a * \exp ( & \frac{-\mathrm{SST}_{[-3,3][3,20 \mathrm{~W}]}^{m^{1}}}{\mathrm{ATL} 3} \\
& +\frac{\mathrm{SST}_{[-10,10][50 \mathrm{E}, 70 \mathrm{E}]}^{m^{2}}-\mathrm{SST}_{[0,10][90 \mathrm{E}, 110 \mathrm{E}]}^{m^{2}}}{\mathrm{IOD}} \\
& \left.+\frac{\mathrm{SST}_{[-5,5][120 \mathrm{~W}, 170 \mathrm{~W}]}^{m^{3}}}{\operatorname{Niño3.4}}\right)+b .
\end{aligned}
$$

In (4), a minus sign is added to those areas of SST which have shown a negative correlation with the NWPR precipitation index. The superscripts indicate SST predictor month defined according Figure 5. For this model, we have achieved a correlation of $\sim 0.85$ between observed and predicted rainfall anomaly of December.

Table 3 presents the input variables (SST used to calculate ATL3, IOD, and Niño3.4 indices) and lags for linear and exponential models. These variables were selected considering the statistically significant correlations between SST and NWPR indices shown in Figure 5. Besides, Table 3 also includes the correlation coefficients between observed and modeled monthly rainfall. In order to validate our proposed models, besides the correlation coefficient (Table 3), we also calculated the mean absolute error (MAE) and the root mean 


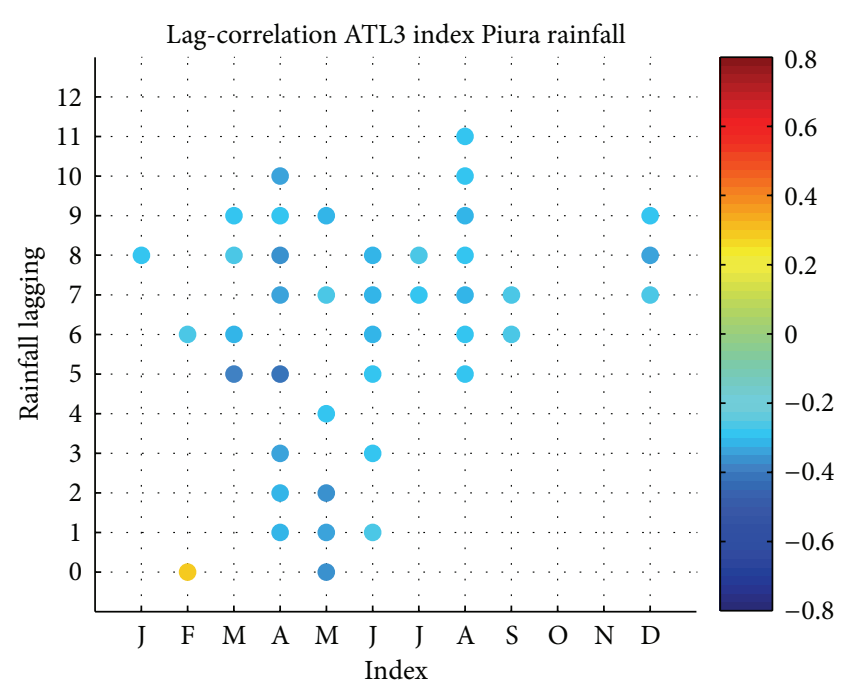

(a)

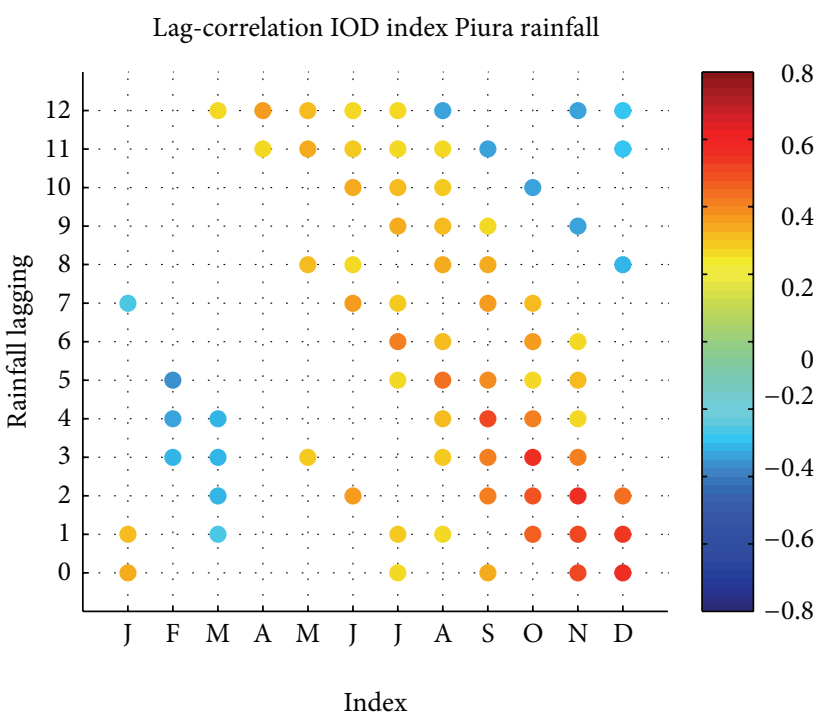

(b)

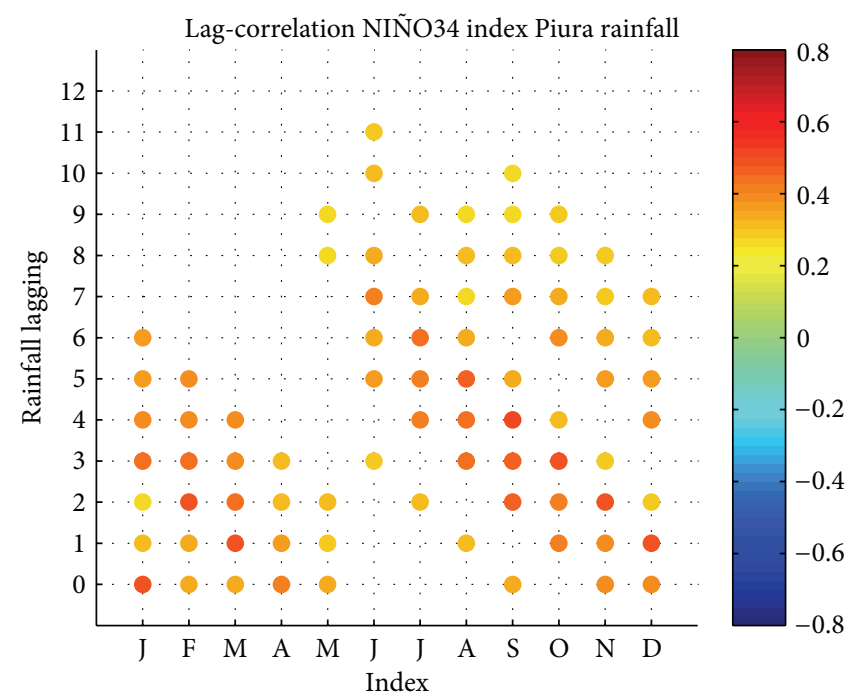

(c)

FIgURE 5: Monthly correlations between the (a) ATL3, (b) IOD, and (c) Niño3.4 indices and the NWPR index from 0 to 12 months lagged.

square error (RMSE) presented in Table 4. All statistical indices considered indicates that the nonlinear model reduces the errors in comparison with the linear model, that is, exponential model provides higher correlation and smaller MAE and RMSE. This might be explained by the nonlinear interactions between the Indian and Pacific Oceans as discussed in the recent study of Taschetto and Ambrizzi [19]. With statistical model proposed for prediction of rainfall, we can implement a system of early warning of floods in the NW Peru. The use of SST anomalies of remote areas helped us to make a forecast with several months in advance.

\section{Conclusions}

Many researches focus in the ENSO impact over Peru, but few studies have reported teleconnections pattern, of Indian and Atlantic Oceans, with potential effects on rainfall in northwestern Peru.

This work has investigated links between SST variations in global oceans and rainfall index in NW Peru (NWPR). We have taken into account seasonal and monthly correlations between SST and NWPR from zero to two seasons of lag and from zero to twelve months of lag. We have applied finiteness and interdependence of the spatial grid criteria to avoid spurious correlations. We found significant lagged seasonal correlations with different tropical areas. These areas are related with the ENSO phenomenon, the Indian Ocean Dipole and the Equatorial Atlantic Oscillation. It is known that in these three areas patterns of SST variability are related with atmospheric circulation patterns.

An analysis of the relationships between SST and rainfall in Tumbes-Piura allowed us to elaborate a linear and an 
TABLE 3: Variables and lags used in the linear and exponential models and correlations between modeled and observed rainfall in NW Peru.

\begin{tabular}{|c|c|c|c|c|c|}
\hline \multirow[b]{2}{*}{ Month } & \multirow[b]{2}{*}{ Parameters models } & \multicolumn{2}{|c|}{ Correlation } & \multicolumn{2}{|c|}{ Constant values } \\
\hline & & Exponential model & Linear model & $\begin{array}{l}\text { Exponential } \\
\text { model (a-b) }\end{array}$ & $\begin{array}{l}\text { Linear model } \\
\quad(a-e)\end{array}$ \\
\hline December & $m^{1}=$ April, $m^{2}=$ October, and $m^{3}=$ November & 0.85 & 0.45 & $\begin{array}{c}(0.8527) \\
(7.2447 e-17)\end{array}$ & $\begin{array}{c}(-31.2257) \\
(56.6475) \\
(-18.5818) \\
(17.2338) \\
(-627.7589) \\
\end{array}$ \\
\hline January & $m^{1}=$ April, $m^{2}=$ November, and $m^{3}=$ December & 0.85 & 0.6 & $\begin{array}{c}(0.8517) \\
(5.7781 e-17)\end{array}$ & $\begin{array}{c}(-23.9076) \\
(222.6269) \\
(-114.2665) \\
(15.4083) \\
(-3.0392 e+03) \\
\end{array}$ \\
\hline February & $m^{1}=$ April, $m^{2}=$ October, and $m^{3}=$ August & 0.78 & 0.42 & $\begin{array}{c}(0.7845) \\
(1.0589 e-16)\end{array}$ & $\begin{array}{c}(-45.1209) \\
(138.8208) \\
(8.2054) \\
(31.6697) \\
(-3.5051 e+03)\end{array}$ \\
\hline March & $m^{1}=$ July, $m^{2}=$ November, and $m^{3}=$ February & 0.75 & 0.5 & $\begin{array}{c}(0.7516) \\
(-4.5024 e-17)\end{array}$ & $\begin{array}{c}(-48.0442) \\
(209.8999) \\
(-59.8236) \\
(16.5632) \\
(-3.4925 e+03)\end{array}$ \\
\hline April & $m^{1}=$ August, $m^{2}=$ October, and $m^{3}=$ February & 0.82 & 0.48 & $\begin{array}{c}(0.8219) \\
(-3.0232 e-16)\end{array}$ & $\begin{array}{c}(-35.4956) \\
(74.0641) \\
(39.4803) \\
(66.5445) \\
(-3.8771 e+03)\end{array}$ \\
\hline May & $m^{1}=$ August, $m^{2}=$ February, and $m^{3}=$ March & 0.85 & 0.43 & $\begin{array}{c}(0.8493) \\
(1.3529 e-16)\end{array}$ & $\begin{array}{c}(-45.0423) \\
(-56.2833) \\
(78.6403) \\
(46.9579) \\
(-586.7617)\end{array}$ \\
\hline
\end{tabular}

TABLE 4: Validation for the linear and exponential models for prediction of monthly rainfall from December to May.

\begin{tabular}{lcccc}
\hline \multirow{2}{*}{ Month } & \multicolumn{2}{c}{ Linear } & \multicolumn{2}{c}{ Exponential } \\
& MAE & RMSE & MAE & RMSE \\
\hline December & 0.76 & 1.03 & 0.28 & 0.52 \\
January & 0.68 & 0.88 & 0.23 & 0.52 \\
February & 0.88 & 1.07 & 0.45 & 0.61 \\
March & 0.81 & 0.98 & 0.45 & 0.65 \\
April & 0.80 & 1.01 & 0.36 & 0.56 \\
May & 0.78 & 1.05 & 0.36 & 0.52 \\
\hline
\end{tabular}

exponential regression models to make monthly predictions of rainfall. We found robust and highly significant lagged correlations between SST indices and rainfall index. The linear regression model shows better skill in the prediction of January rainfall anomaly, when the correlation coefficient is the highest (0.6). However, considering all the period tested, the exponential relationship between SST and rainfall [12] provides better results. This exponential model improves the correlation in all analyzed months, especially in December,
February, and May. Considering the performance of the linear and exponential models, smaller absolute error and root mean square error are obtained with the exponential model.

In the present study, we find that despite being a remote response to ENSO events, the Indian Ocean has the potential to feedback onto the atmosphere and induce tropical and extratropical teleconnections over South America. This is in agreement with Taschetto and Ambrizzi [19] results that present evidences that South America rainfall (including Northwestern Peru) can be modulated by Indian Ocean SST variability via remote mechanisms. Furthermore, Wang et al. [36] explained teleconnetions patterns between the Indian, Atlantic, and Pacific Oceans and rainfall variability over South America.

The most important result is that the rainfall in NW of Peru is influenced by other areas besides ENSO areas, with several months in advance, which are related with known indices like the Indian Dipole Ocean or the equatorial Atlantic Oscillation. These results open new possibilities to understand and to monitor the rainfall in NW of Peru.

We consider future research studies on El Niño Modoki impacts on Peruvian rainfall variability. Tedeschi et al. [44] 
presents different oceanic and atmospheric patterns when compared to Canonical ENSO. The impacts on South America precipitation indicate the importance of studying the two types separately.

Finally, we propose that further research should be conducted to study the mechanism involved in the correlations obtained in this study using atmospheric general circulation model (AGCM) and regional climate model (RCM). The first one would be used to assess the influence of SST over the circulation affecting the area under study and to provide boundary conditions to the RCM.

The RCM itself could provide the physical link between SST and rainfall, since AGCMs have difficulties with the distribution of precipitation and a dynamical downscaling may be needed [45].

\section{Acknowledgments}

This work was supported by "Xunta de Galicia" under Project 10PXIB383169PR and cofinanced by European Regional Development Fund (FEDER). This work was partially supported by Xunta de Galicia under the Programa de Consolidación e Estruturación de Unidades de Investigación (Grupos de Referencia Competitiva) funded by European Regional Development Fund (FEDER). CNPq (Grant 307202/2011-9) has also supported partially this work. The authors wish to thank Rita Ynoue for the English proofing and wish to thank the anonymous reviewers.

\section{References}

[1] A. G. Barnston, "Linear statistical short-term climate predictive skill in the Northern Hemisphere," Journal of Climate, vol. 7, pp. 1513-1564, 1994.

[2] D. P. Rowell, "Assessing potential seasonal predictability with an ensemble of multidecadal GCM simulations," Journal of Climate, vol. 11, no. 2, pp. 109-120, 1998.

[3] A. G. Barnston and T. M. Smith, "Specification and prediction of global surface temperature and precipitation from global SST using CCA," Journal of Climate, vol. 9, no. 11, pp. 2660-2697, 1996.

[4] M. J. Rodwell, D. P. Rowell, and C. K. Folland, "Oceanic forcing of the wintertime North Atlantic Oscillation and European climate," Nature, vol. 398, no. 6725, pp. 320-323, 1999.

[5] M. Drévillon, L. Terray, P. Rogel, and C. Cassou, "Mid latitude Atlantic SST influence on European winter climate variability in the NCEP reanalysis," Climate Dynamics, vol. 18, no. 3-4, pp. 331-344, 2001.

[6] M. N. Lorenzo, J. J. Taboada, I. Iglesias, and M. GómezGesteira, "Predictability of the spring rainfall in North-west of Iberian from sea surfaces temperatures of ENSO areas," Climatic Change, vol. 107, no. 3-4, pp. 329-341, 2011.

[7] A. M. S. Delitala, D. Cesari, P. A. Chessa, and M. N. Ward, "Precipitation over Sardinia (Italy) during the 1946-1993 rainy seasons and associated large scale climate variations," International Journal of Climatology, vol. 20, pp. 519-541, 2000.

[8] I. D. Phillips and G. R. Mcgregor, "The relationship between monthly and seasonal South-West England rainfall anomalies and concurrent North Atlantic sea surface temperatures," International Journal of Climatology, vol. 22, no. 2, pp. 197-217, 2002.
[9] I. D. Phillips and J. Thorpe, "Icelandic precipitation-North Atlantic sea-surface temperature associations," International Journal of Climatology, vol. 26, no. 9, pp. 1201-1221, 2006.

[10] M. N. Lorenzo, I. Iglesias, J. J. Taboada, and M. GómezGesteira, "Relationship between monthly rainfall in Northwest Iberian Peninsula and North Atlantic Sea surface temperature," International Journal of Climatology, vol. 30, no. 7, pp. 980-990, 2010.

[11] P. Lagos, Y. Silva, E. Nickl, and K. Mosquera, "El Niño, Climate Variability and Precipitation Extremes in Perú," Advanced Geosciences, vol. 14, pp. 231-237, 2008.

[12] R. Woodman, "Modelo estadístico de pronóstico de las precipitaciones en la costa norte del Peru," El Fenómeno El Niño. Investigación para una prognosis, ler encuentro de Universidades del Pacifico Sur: Memoria 93-108, Piura-Peru, 1999.

[13] M. Vuille, R. S. Bradley, and F. Keimig, "Climate variability in the Andes of Ecuador and its relation to tropical Pacific and Atlantic Sea Surface temperature anomalies," Journal of Climate, vol. 13, no. 14, pp. 2520-2535, 2000.

[14] M. H. González and C. S. Vera, "On the interannual wintertime rainfall variability in the Southern Andes," International Journal of Climatology, vol. 30, no. 5, pp. 643-657, 2010.

[15] J. Zhou and K.-M. Lau, "Principal modes of interannual and decadal variability of summer rainfall over South America," International Journal of Climatology, vol. 21, no. 13, pp. 1623$1644,2001$.

[16] K. Takahashi, "The atmospheric circulation associated with extreme rainfall events in Piura, Peru, during the 1997-1998 and 2002 El Niño events," Annales Geophysicae, vol. 22, no. 11, pp. 3917-3926, 2004.

[17] S. C. Chan, S. K. Behera, and T. Yamagata, "Indian Ocean Dipole influence on South American rainfall," Geophysical Research Letters, vol. 35, no. 14, pp. 10-14, 2008.

[18] A. R. Drumond de M and T. Ambrizzi, "The role of the South Indian and Pacific oceans in South American monsoon variability. Find out how to access preview-only content," Theoretical and Applied Climatology, vol. 94, no. 3-4, pp. 125137, 2008.

[19] A. S. Taschetto and T. Ambrizzi, "Can Indian Ocean SST anomalies influence South American rainfall?" Climate Dynamics, vol. 38, no. 7-8, pp. 1615-1628, 2012.

[20] L. M. V. Carvalho, C. Jones, A. E. Silva, B. Liebmann, and P. L. Silva Dias, "The South American Monsoon System and the 1970s climate transition," International Journal of Climatology, vol. 31, no. 8, pp. 1248-1256, 2011.

[21] R. C. Murphy, "Oceanic and climatic phenomena along the west coast of South America during 1925," Geographical Review, vol. 16, pp. 26-54, 1926.

[22] C. N. Caviedes, "El Niño 1972: its climatic, ecological, human and economic implications," Geographical Review, vol. 65, no. 4, pp. 494-509, 1975.

[23] C. N. Caviedes, “El Niño 1982-83," Geographical Review, vol. 74, no. 3, pp. 267-290, 1984.

[24] D. B. Enfield, "Progress in understanding El Niño," Endeavour, vol. 11, no. 4, pp. 197-204, 1987.

[25] S. Zuta and O. Guillén, "Oceanografía de las aguas costeras del Perú," El Boletín del Instituto del Mar del Perú, vol. 2, no. 5, pp. 157-324, 1970.

[26] R. Mugica, "Oceanografía del mar peruano," in Historia Marítima Del Perú, vol. I, no. I, pp. 216-474, 1972. 
[27] M. T. Gilfort, M. J. Vojtesak, G. Myles, R. C Bonan, and D. L. Martens, South America: South of the Amazon River A Climatology Study, Environmental Technical Application Center, 1992.

[28] P. Waylen and G. Poveda, "El Nino-Southern Oscillation and aspects of western South American hydro-climatology," Hydrological Processes, vol. 16, no. 6, pp. 1247-1260, 2002.

[29] M. W. Douglas, M. Pena, N. Ordinola et al., "Synoptic and spatial variability of the rainfall along the northern Peruvian coast during the 1997-8 El Nino event," in Proceedings of the Sixth International Conference on Southern Hemisphere Meteorology,, pp. 104-105, Santiago, Chile, 2000.

[30] T. D. Tapley Jr. and P. R. Waylen, "Spatial variability of annual precipitation and ENSO events in western Peru," Hydrological Sciences Journal/Journal des Sciences Hydrologiques, vol. 35, no. 4, pp. 429-446, 1990.

[31] R. A. Goldberg, G. Tisnado, and R. A. Scofield, "Characteristics of extreme rainfall events in north-western Peru during the 1982-1983 El Nino period," Journal of Geophysical Research, vol. 92, no. C13, pp. 14225-14241, 1987.

[32] J. D. Horel and A. G. Cornejo-Garrido, "Convection along the coast of northern Peru during 1983: spatial and temporal variation of clouds and rainfall," Monthly Weather Review, vol. 114, no. 11, pp. 2091-2105, 1986.

[33] N. H. Saji, B. N. Goswami, P. N. Vinayachandran, and T. Yamagata, "A dipole mode in the tropical Indian ocean," Nature, vol. 401, no. 6751, pp. 360-363, 1999.

[34] M. Vuille, R. S. Bradley, and F. Keimig, "Interannual climate variability in the Central Andes and its relation to tropical Pacific and Atlantic forcing," Journal of Geophysical Research D, vol. 105, no. 10, pp. 12447-12460, 2000.

[35] J. H. Yoon and N. Zeng, "An Atlantic Influence on Amazon rainfall," Climate Dynamics, vol. 34, no. 2-3, pp. 249-264, 2009.

[36] C. Wang, F. Kucharski, R. Barimalala, and A. Bracco, "Teleconnections of the tropical Atlantic to the tropical Indian and Pacific Oceans: a review of recent findings," Meteorologische Zeitschrift, vol. 18, no. 4, pp. 445-454, 2009.

[37] T. C. Peterson, R. Vose, R. Schmoyer, and V. Razuvaev, "Global historical climatology network (GHCN) quality control of monthly temperature data," International Journal of Climatology, vol. 18, no. 11, pp. 1169-1179, 1998.

[38] I. D. Philips and G. R. McGregor, "Western European water vapor flux-southwest England rainfall associations," Journal of Hydrometeorology, vol. 5, pp. 505-523, 2001.

[39] T. M. . Smith and R. W. Reynolds, "Improved Extended Reconstruction of SST, (1854-1997)," Journal of Climate, vol. 17, pp. 2466-2477, 2004.

[40] S. E. Zebiak, "Air-sea interaction in the equatorial Atlantic region," Journal of Climate, vol. 6, no. 8, pp. 1567-1586, 1993.

[41] K. E. Trenberth, "The definition of El Niño," Bulletin of the American Meteorological Society, vol. 78, no. 12, pp. 2771-2777, 1997.

[42] S. A. Klein, B. J. Soden, and N. C. Lau, "Remote sea surface temperature variations during ENSO: evidence for a tropical atmospheric bridge," Journal of Climate, vol. 12, no. 4, pp. 917932, 1999.

[43] J. C. H. Chiang and A. H. Sobel, "Tropical tropospheric temperature variations caused by ENSO and their influence on the remote tropical climate," Journal of Climate, vol. 15, no. 18, pp. 2616-2631, 2002.

[44] R. G. Tedeschi, I. F. A. Cavalcanti, and A. M. Grimm, "Influences of two types of ENSO on South American precipitation," International Journal of Climatology, 2012.
[45] F. Giorgi and L. O. Mearns, "Introduction to special section: regional climate modeling revisited," Journal of Geophysical Research, vol. 104, no. D6, pp. 6335-6352, 1999. 

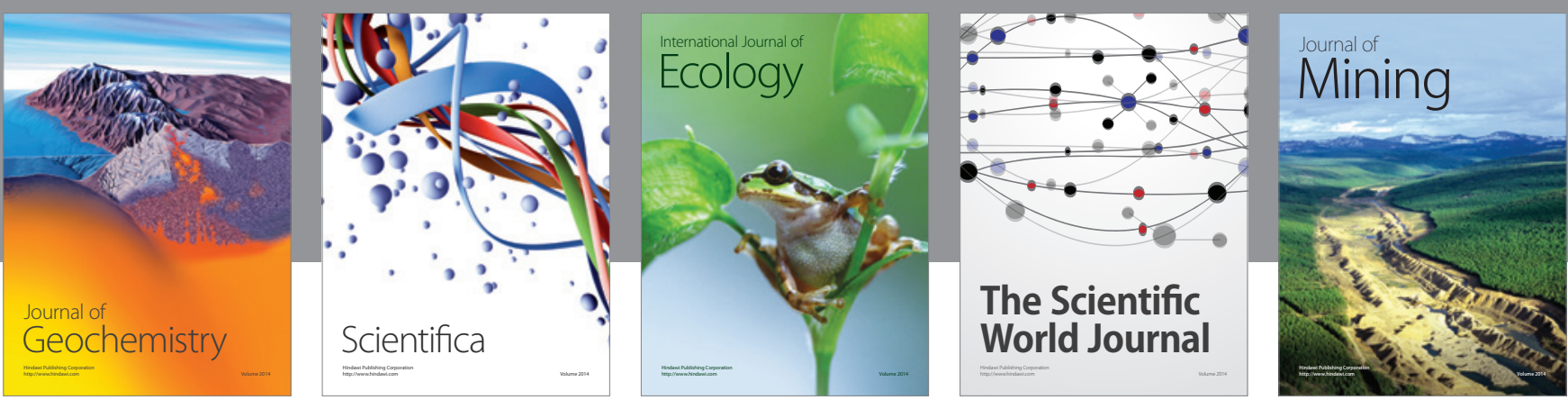

The Scientific World Journal
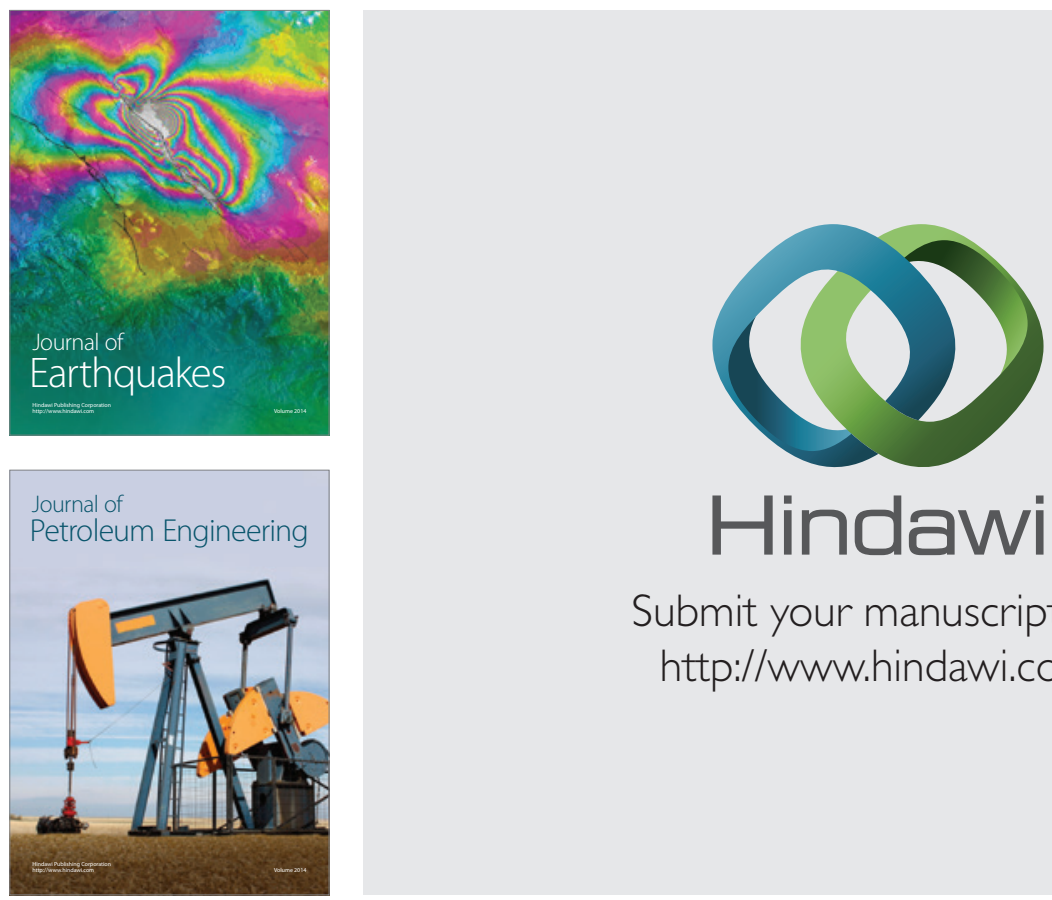

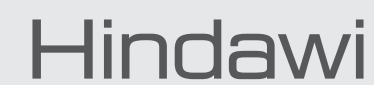

Submit your manuscripts at

http://www.hindawi.com
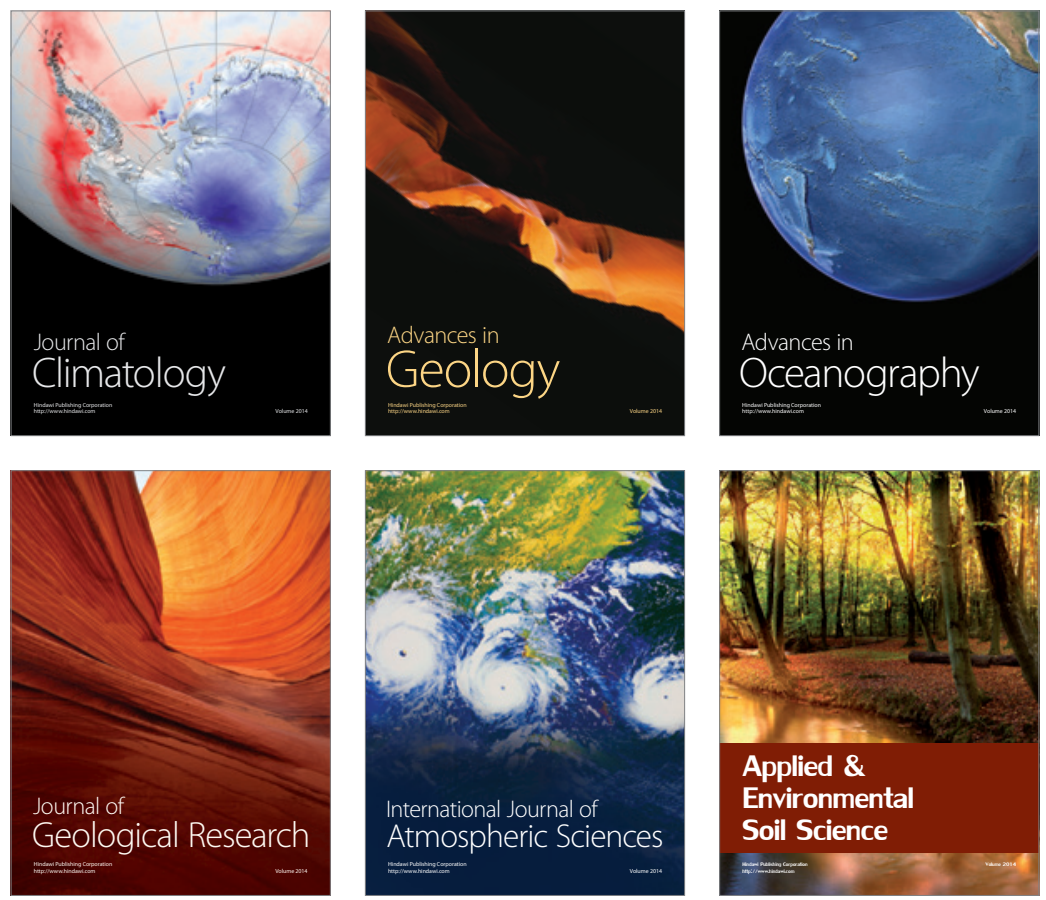
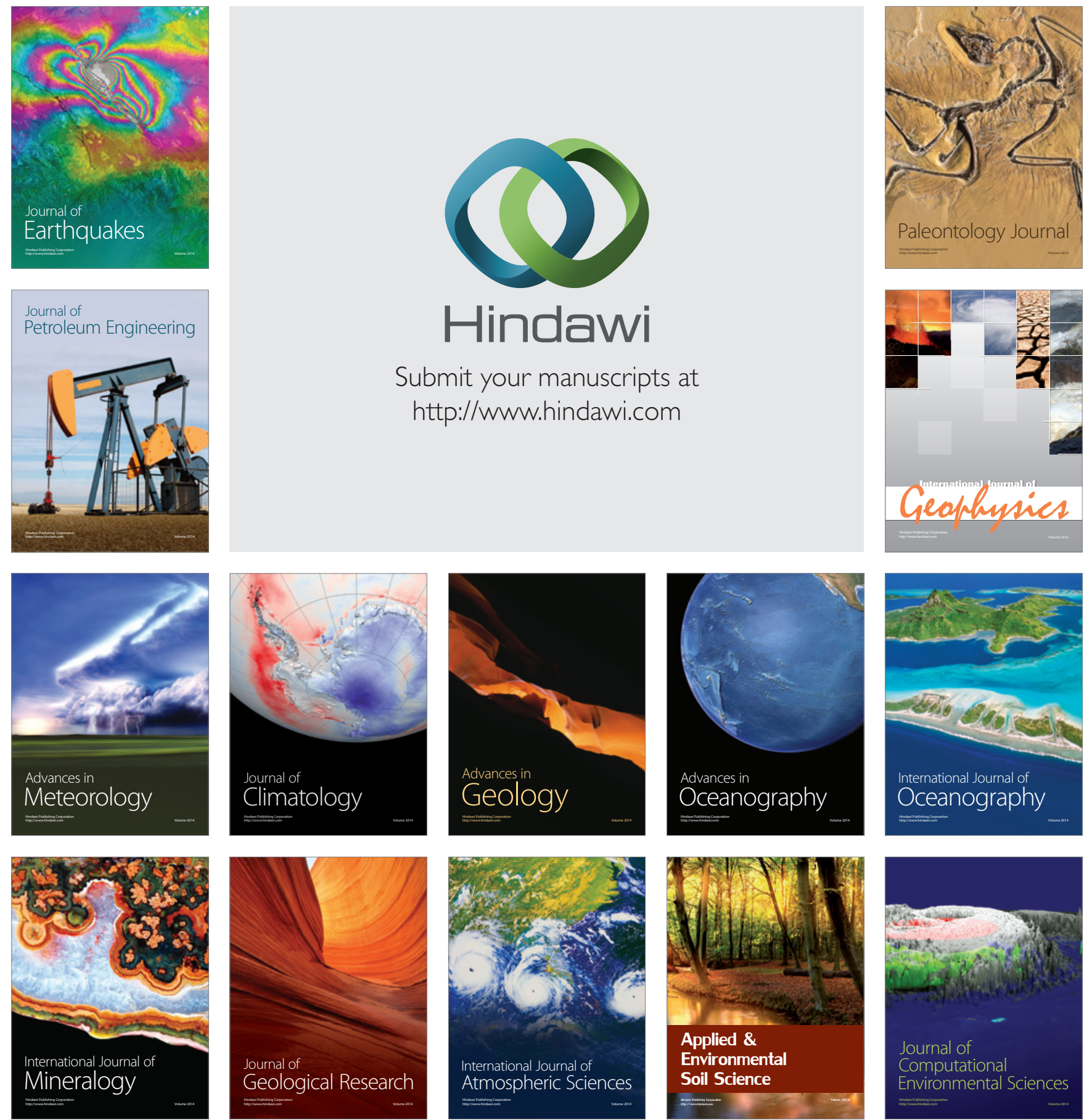